\title{
Pelanggaran Standar Operasional Prosedur Produksi Teh Iroet
}

\section{(Violation of Standard Operation Procedures of Iroet Tea Production)}

\author{
Al Fattaah Muhammad Syah Fisabilillah ${ }^{1{ }^{*}}$, Lucyana Trimo ${ }^{1)}$ \\ 1) Program Studi Agribisnis Universitas Padjadjaran Jl. Raya Bandung-Sumedang Km. 21, \\ Jatinangor, Kabupaten Sumedang, Jawa Barat, Kode Pos 45363 \\ E-mail: alfattaahmsf@gmail.com
}

\begin{abstract}
Iroet Tea is a dry tea trademark owned by Koperasi Serba Usaha (KSU) Putera Mekar. Iroet tea products have been certified UTZ number two in the world and number one in Indonesia related to good plantation practices, good tea processing, environmental social issues, food safety, and quality improvement. Iroet Tea earned UTZ certificates in 2011 and 2013, but currently does not receive the certification, because there are many violations of the standard production procedures, so please note what violations that occur during the production process. The research design used in this research is qualitative with case study technique. The method used in this research is descriptive qualitative. KSU Putera Mekar has set the standard opertaion procedure since the process of picking shoots until dry tea processing process, so that if farmers and workers follow the standard procedure, then Iroet tea products produced will be good quality and get UTZ certificate. But many violations Iroet tea standard operation procedures, from picking tea shoots, shoots at the shelter collecting the results, to the processing of dried tea is done at the factory. The results showed that there were many violations during the process of supplying raw materials to the production process, the violations committed in the form of non compliance with standard operation procedures and agreements related to raw materials needed, the process of gathering raw materials, and processing of dry tea.
\end{abstract}

Keywords: production, quality control, standard operation procedure, tea

DOI: http://dx.doi.org/ 10.25181/jaip.v6i1.776

Diterima: 18 Maret 2018 / Disetujui: 15 Mei 2018 / Diterbitkan: 23 Mei 2018

\section{PENDAHULUAN}

Teh merupakan salah satu minuman terpopuler yang memiliki banyak manfaat bagi kesehatan tubuh. Hal ini karena teh mengandung senyawa-senyawa bermanfaat seperti polifenol, theofilin, flavonoid/metilxantin, tanin, vitamin C dan E, katekin, serta sejumlah mineral seperti Zn, Se, Mo, Ge, dan Mg (Kusmiyati et al., 2015; Anjarsari, 2016). Menurut Direktorat Jenderal Perkebunan Indonesia, komoditas teh (Camellia sinensis) memberikan kontribusi yang besar bagi perekonomian negara melalui devisa yang dihasilkan, termasuk menjadi sektor unggulan yang mampu menyerap tenaga kerja dalam jumlah yang besar. Pengusahaan komoditas teh terbagi atas Perkebunan Rakyat, Perkebunan Negara, dan Perkebunan Swasta. Perkebunan teh rakyat di Indonesia memiliki potensi untuk membangkitkan industri teh nasional karena berdasarkan data statistik, luas lahan terbesar merupakan Perkebunan Rakyat (Anjarsari, 2016). 
Tabel 1. Luas areal dan produksi teh di Indonesia menurut status pengusahaan tahun 2016

\begin{tabular}{lccc}
\hline \multicolumn{1}{c}{ Pelaku } & Luas Areal (ha) & Produksi (ton) & Produktivitas (ton.ha $^{-1}$ ) \\
\hline Perkebunan Rakyat & 53.358 & 50.856 & 0,95 \\
Perkebunan Besar Negara & 37.398 & 65.343 & 1,75 \\
Perkebunan Besar Swasta & 28.143 & 38.170 & 1,36 \\
Keseluruhan (Nasional) & 118.899 & 154.369 & 1,30 \\
\hline
\end{tabular}

Sumber: Direktorat Jenderal Perkebunan (2016)

Perkebunan teh rakyat di Indonesia berpotensi untuk membangkitkan industri teh nasional karena proporsi luas area perkebunan teh rakyat yang besar dan pertumbuhan produksi yang cenderung meningkat (Trimo \& Nurafifah, 2017). Meskipun demikian, produktivitas perkebunan teh rakyat masih sangat rendah dibanding perkebunan besar nasional maupun swasta (Novasyurahati, 2014). Pengembangan agribisnis teh menemui beberapa kendala pada perkebunan rakyat. Kondisi yang memprihatinkan ditunjukkan dengan berkembangnya upaya-upaya konversi tanaman teh ke komoditas lainnya oleh para pelaku teh sendiri. Perkebunan teh rakyat di Jawa Barat mengalami penurunan areal lahan dalam beberapa waktu terakhir akibat maraknya alih fungsi lahan (Wulansari et al., 2017). Luas areal perkebunan teh rakyat di Jawa Barat dari 56.000 ha pada 2004 hanya menyisakan 53.538 ha pada 2016.

Produktivitas perkebunan teh rakyat pun rendah disebabkan oleh kualitas bahan tanaman yang rendah, sebagian besar pertanaman merupakan tanaman tua, penerapan teknik budidaya yang kurang tepat, dan penggunaan input yang terbatas. Harga pucuk di tingkat petani masih rendah. Selain itu, kondisi perkebunan teh rakyat pada umumnya memiliki populasi tanaman yang tidak sesuai dengan jumlah standar teknis populasi yaitu sekitar 10.000 pohon teh per ha. Kondisi yang ada saat ini, populasi tanaman teh rakyat hanya sekitar separuh dari populasi optimal atau kurang (Trimo et al., 2017). Meningkatkan kualitas produk hilir teh indonesia terutama teh kering hijau curah merupakan upaya untuk mendorong penjualan teh di indonesia, dan dapat meningkatkan daya saing petani teh rakyat (Suprihatini, 2015).

Petani teh rakyat di Desa Sukatani, Kecamatan Cilawu, Kabupaten Garut yang dikelola melalui kelembagaan Koperasi Serba Usaha (KSU) Putera Mekar, pada awalnya hanya mengirim pucuk teh basah kepada PTPN VIII karena tidak memiliki unit pengolahan teh kering, hingga pada tahun 2012 PTPN VIII memutuskan untuk tidak melanjutkan kerjasama dengan KSU Putera Mekar. Oleh karena itu, BWI (Business Watch Indonesia) berniat untuk membimbing dan mengajarkan petani teh rakyat dari KSU Putera Mekar untuk mengolah pucuk teh basah menjadi daun teh kering denganbantuan pembekalan materi dari PT Sariwangi. Maka dari itu, Pabrik Teh Iroet yang dimiliki KSU Putera Mekar dibangun untuk mengurangi tingkat ketergantungan petani terhadap pengelolaan swasta dan meningkatkan pendapatan petani dari nilai tambah produk teh 
yang dihasilkan, dan KSU Putera Mekar memiliki merk dagang teh kering bernama Teh Iroet. Pabrik tersebut dibangun dari inisiatif petani sendiri dengan menggunakan modal pinjaman dari BWI (Business Watch Indonesia).

Koperasi ini menunjukkan bahwa teh rakyat pun dapat dikelola secara mandiri. KSU Putera Mekar beranggotakan 454 orang petani yang memiliki perkebunan teh rakyat dengan total luas 406,51 hektar. Pengurus koperasi juga telah menetapkan standar prosedur produksi teh Iroet agar kualitas produknya terjaga. Pabrik Teh Iroet memiliki kapasitas produksi 8,5 ton pucuk basah per hari dan menghasilkan 50 ton teh kering per bulan yang seluruhnya dipasarkan sendiri. Secara total, KSU Putera Mekar mengelola 600 ton teh kering per tahun yang setara dengan USD 1,62 juta. KSU Putera Mekar merupakan koperasi teh rakyat yang mendapatkan sertifikat UTZ nomor dua di dunia dan nomor satu di Indonesia. Sertifikasi ini memperhatikan penerapan praktik perkebunan yang baik, persoalan-persoalan sosial dan lingkungan, keamanan pangan, dan peningkatan kualitas.

Kondisi tersebut hanya bertahan sementara, karena pada tahun 2015 PT Sariwangi sebagai konsumen terbesar KSU Putera Mekar memutuskan kontrak kerjasamanya, sehingga KSU Putera Mekar tidak lagi menyuplai teh kering ke PT. Sariwangi, hal ini menyebabkan anggota koperasi semakin berkurang dari 454 orang menjadi 186 orang. Kondisi KSU Putera Mekar semakin memburuk, karena kualitas bahan baku pada tahapan pemetikan pucuk basah, proses produksi teh kering iroet, sortasi dan grading tidak dikendalikan dengan baik. Banyak pelanggaran terhadap standar prosedur yang dilakukan oleh petani dan pekerja yang terlibat dalam proses produksi teh Iroet, sehingga perlu dianalisis pelanggaran standar prosedur produksi teh Iroet.

\section{METODE PENELITIAN}

Penelitian dilakukan mulai Juni sampai dengan November 2017. Objek yang diteliti adalah Pelanggaran Standar Operasional Produksi Teh Iroet. Subjek yang diteliti adalah produk teh kering yang diolah di pabrik pengolahan teh milik Koperasi Serba Usaha (KSU) Putera Mekar, Desa Sukatani, Kecamatan Cilawu, Kabupaten Garut serta pihak-pihak yang terlibat dalam pengendalian kualitas di KSU Putera Mekar seperti pekerja dan pihak swasta. Pemilihan KSU Putera Mekar sebagai lokasi penelitian dilakukan secara sengaja (purposive) karena KSU Putera Mekar adalah koperasi yang beranggotakan petani teh rakyat di Kabupaten Garut. KSU ini pun telah memiliki pabrik pengolahan teh sendiri yang merupakan pertama di Indonesia.

Desain penelitian yang digunakan dalam penelitian ini adalah desain kualitatif dengan teknik studi kasus. Penelitian kualitatif memberikan penggambaran secara mendalam mengenai situasi atau proses yang diteliti. Pendekatan kualitatif dalam penelitian ini digunakan untuk menghasilkan data deskriptif berupa kata-kata lisan atau tulisan dari manusia atau tentang perilaku manusia yang dapat diamati (Sugiyono, 2013). 
Teknik penelitian yang digunakan dalam penelitian ini adalah studi kasus. Menurut Moleong (1999), studi kasus objek peristiwanya hanya satu unit kasus, dapat berupa kesatuan sosial tertentu, seorang, satu keluarga, suatu kelompok atau organisasi dalam suatu masyarakat, suatu komunitas tertentu dan sebagainya.

Teknik analisis yang digunakan dalam penelitian ini adalah teknik deskriptif. Suharsimi Arikunto (2005) mengungkapkan bahwa penelitian deskriptif merupakan penelitian yang bertujuan untuk menggambarkan "apa adanya" tentang suatu variabel, gejala, atau keadaan. Penelitian deskriptif tidak bertujuan untuk menguji hipotesis, melainkan untuk menemukan teori di lapangan (Suharsimi, 2010). Metode deskriptif kualitatif adalah suatu metode yang digunakan untuk menemukan pengetahuan terhadap subjek penelitian pada suatu saat tertentu. Metode deskriptif kualitatif berusaha mendeskripsikan seluruh gejala atau keadaan yang ada, yaitu keadaan gejala menurut apa adanya pada saat penelitian dilakukan (Balqis et al., 2014).

\section{HASIL DAN PEMBAHASAN}

Pengolahan teh hijau dan teh hitam memiliki sistem yang berbeda, pada pengolahan teh hitam proses pengolahannya terbagi menjadi dua sistem, yaitu sistem Ortodox dan CTC (Crushing Tearing Curling) (Anggraini et al., 2016). Pengolahan teh hijau Indonesia menganut serangkaian proses fisik dan mekanis tanpa atau sedikit mengalami proses oksimatis terhadap daun teh melalui sistem sangrai. Berdasarkan proses pengolahannya, jenis teh dapat dibedakan menjadi teh tanpa fermentasi (teh putih dan teh hijau), teh semi fermentasi (teh oolong), serta teh fermentasi (teh hitam). Teh Iroet merupakan teh hijau atau teh tanpa fermentasi (Rohdiana, 2015). KSU Putera Mekar telah menetapkan standar prosedur produksi teh Iroet sejak awal pabrik teh Iroet berdiri. Standar prosedur produksi teh iroet dimulai dari proses pemetikan pucuk teh basah, pengumpulan pucuk basah di Tempat Penampungan Hasil (TPH), dan empat tahap pengolahan pucuk basah menjadi teh kering yaitu proses pelayuan, penggulungan, pengeringan, serta sortasi dan grading. Standar prosedur produksi teh Iroet dapat dilihat pada Tabel 2.

Standar operasional prosedur yang dibuat oleh KSU Putera Mekar bertujuan untuk yang memperhatikan praktik perkebunan yang baik, persoalan-persoalan sosial dan lingkungan, serta keamanan pangan dan peningkatan kualitas, sehingga produk teh Iroet dapat menerima sertifikasi UTZ kembali. Sejak 2015 produk teh Iroet sudah tidak menerima serifikasi UTZ karena banyak terjadi pelanggaran pada standar prosedur proses produksi, hal ini menyebabkan kualitas produk teh Iroet memburuk. Berikut ini adalah deskripsi pelanggaran yang dilakukan oleh petani dan pekerja yang terlibat dalam proses produksi teh Iroet. 
Tabel 2. Standar prosedur produksi teh Iroet

Standar Prosedur Produksi Teh Iroet

\section{Pemetikan Pucuk}

Koperasi meminta petani untuk memetik pucuk dengan rumusan petikan medium $(p+2$ dan $p+3)$

\section{Tempat Penampungan Hasil (TPH)}

Petugas harus mengelompokkan petikan pucuk berdasarkan rumusan petikannya dan memasukkan maksimal $25 \mathrm{Kg}$ pucuk basah dalam satu karung.

\section{Proses Pelayuan}

Pekerja pabrik harus memasukkan maksimal 25Kg pucuk basah ke dalam mesin Rottary Panner dalam satu kali proses pelayuan agar pelayuan merata dan optimal.

\section{Proses Penggulungan}

Pekerja pabrik harus memasukkan pucuk yang sudah dilayukan sebanyak 5-10Kg kedalam mesin Jackson, dan memberikan wadah dibawah mesin agar pucuk yang sudah digulung tidak jatuh ke lantai dan kotor.

\section{Proses Pengeringan}

Pucuk yang telah dilayukan dan digulung harus dikeringkan melalui dua tahap, agar dapat mengurangi kadar air hingga 96\%, memperbaiki gulungan teh kering, menjaga warna teh agar tidak coklat, dan menciptakan aroma teh kering yang khas. Pengeringan pertama dilakukan di mesin Repeat selama 25 menit dengan suhu $50-55^{\circ} \mathrm{C}$, dan pengeringan kedua dilakukan di mesin Balltea selama 80-90 menit dengan suhu $65-70^{\circ} \mathrm{C}$.

\section{Sortasi dan Grading}

Pada tahap sortasi, pekerja harus memisahkan batang dan dust (debu) yang terbawa saat proses pengolahan dari teh kering.

Pada tahap Grading pekerja harus memisahkan teh kering berdasarkan rumusan petikannya.

- Pemetikan Pucuk

Pemetikan teh dapat dilakukan dengan berbagai cara, diantaranya adalah menggunakan gunting, arit atau clurit, dan menggunakan jari tangan. Diantara semua metode pemetikan tersebut, metode yang paling baik digunakan adalah menggunakan jari tangan (Johan et al., 2009). Petani mitra KSU Putera Mekar melakukan pemetikan pucuk teh dengan cara manual yaitu menggunakan tangan. Metode ini seharusnya efektif karena petani dapat memilih pucuk yang dipetik dengan detil dan seksama, namun petani mitra KSU Putera Mekar tetap saja memetik pucuk yang tidak sesuai kriteria yang diminta. KSU Putera Mekar meminta para petani mitranya untuk memetik pucuk dengan rumusan petikan medium, yaitu $\mathrm{p}+2$ atau $\mathrm{p}+3$. Namun petani mitra justru memetik dengan rumusan campuran antara petikan medium $(p+2$ dan $p+3)$ 
dengan petikan kasar yaitu p+4 atau lebih. Hal ini menyebabkan kualitas teh kering Iroet menjadi buruk karena bahan baku yang diolah bukan bahan baku dengan kualitas bagus.

- Pengumpulan Pucuk

Proses pengumpulan pucuk dilakukan di tempat penampungan hasil (TPH), pada tahapan ini tidak ada penanggung jawab yang bertugas memisahkan dan menggolongkan hasil petikan sesuai rumusannya. Hal ini menyebabkan tercampurnya hasil petikan medium dan petikan kasar, sehingga pucuk teh yang halus tercampur dengan pucuk kasar dan batang. Setelah itu, pucuk yang dikumpulkan akan dimasukkan sebanyak-banyaknya kedalam karung untuk dibawa ke pabrik Teh Iroet, hal ini juga dapat membuat pucuk muda menjadi rusak karena tertumpuk, sehingga menyebabkan menurunnya kualitas teh kering Iroet. Seharusnya pucuk yang dimasukkan ke dalam karung tidak boleh lebih dari $25 \mathrm{~kg}$, namun petugas TPH sering memasukkan pucuk sebanyak 35-40 kg dalam satu karung.

- Proses Pelayuan

Pelayuan pada pengolahan teh bertujuan untuk menonaktifkan enzim polifenol oksidasi dan menurunkan kandungan air dalam pucuk hingga menjadi lentur dan mudah tergulung. Proses pelayuan adalah proses produksi teh kering paling pertama yang dilakukan di pabrik Teh Iroet, pelayuan daun teh dilakukan pada mesin Rotary Panner dalam keadaan panas $80-100^{\circ} \mathrm{C}$ selama 3-5 menit. Proses ini bertujuan untuk melenturkan daun sehingga mudah digulung pada proses selanjutnya. Pengendalian kualitas pada tahapan ini dapat dikatakan cukup buruk, karena para pekerja tidak menjaga kebersihan pabrik sehingga banyak abu dan debu yang masuk kedalam mesin pelayuannya. Selain itu, para pekerja juga memasukkan pucuk basah kedalam mesin pelayuan dengan jumlah besar yang melebihi standar, sehingga pelayuan tidak terjadi dengan maksimal pada beberapa pucuk basah dan menyebabkan kualitas teh kering Iroet menjadi menurun.Standar prosedur yang digunakan pada mesin Rotary Panner adalah $25 \mathrm{~kg}$ pucuk basah untuk sekali proses pelayuan, sedangkan para pekerja koperasi memasukkan 35-40 $\mathrm{kg}$ pucuk basah dalam sekali proses pelayuan.

- Proses Penggulungan

Proses penggulungan merupakan tahapan pengolahan yang bertujuan untuk membentuk mutu secara fisik. Selama proses penggulungan daun teh akan dibentuk menjadi gulungan kecil (Wibowo \& Ramadian, 2010). Proses ini dilakukan pada mesin Jackson tipe Single Action selama 15-20 menit.

Pengendalian kualitas pada proses ini dapat dikatakan cukup baik, karena pekerja melakukan proses penggulungan sesuai dengan standar yang ditetapkan, yaitu kapasitas pucuk basah pada mesin Jackson dapat dimasukkan hingga penuh kedalam lubang pada bagian atas mesin tersebut, yaitu sekitar 5-10kg dalam sekali penggulungan. Pekerja juga harus memberikan wadah pada bagian bawah mesin agar pucuk yang telah digulung dapat terjaga kebersihannya. 
Pekerja telah mengikuti standar kapasitas mesin, namun pekerja tidak menjaga kebersihan pucuk sejak setelah proses pelayuan selesai dan saat proses penggulungan selesai, karena pada saat tersebut pucuk dibiarkan jatuh begitu saja di lantai pabrik yang terdapat banyak debu dan pasir. Hal ini menyebabkan pucuk menjadi kotor dan kualitasnya menjadi menurun.

- Proses Pengeringan

Pengeringan bertujuan untuk mereduksi kandungan air dalam daun hingga 3-4\%. Standar prosedur untuk mencapai kadar air yang demikian rendahnya adalah pengeringan harus dilakukan dalam dua tahap. Pengeringan pertama bertujuan mereduksi kandungan air dan memekatkan cairan sel yang menempel pada permukaan daun. Pengeringan pertama dilakukan selama 25 menit dengan suhu $50-55{ }^{\circ} \mathrm{C}$, dan pengeringan kedua dilakukan selama 80-90 menit dengan suhu $65-70{ }^{\circ} \mathrm{C}$. Hasil pengeringan pertama masih setengah kering dengan tingkat kekeringan (kering dibagi basah) sekira 30-35\%. Disamping memperbaiki bentuk gulungan, pengeringan kedua bertujuan untuk mengeringan teh sampai kadar airnya menyentuh angka 3$4 \%$, menjaga warna teh agar tidak terlalu coklat, dan mengeluarkan aroma teh kering yang khas. Mesin yang digunakan oleh KSU Putera Mekar dalam proses pengeringan pertama adalah mesin Repeat dan pada pengeringan kedua adalah mesin Balltea.

KSU Putera Mekar tidak mengendalikan kualitas dengan baik pada proses ini, karena koperasi hanya melakukan pengeringan sekali saja menggunakan mesin repeat, hal ini tidak sesuai dengan standar prosedur sehingga teh kering Iroet masih dapat dikatakan setengah kering dan tidak menggulung dengan baik. Proses pengendalian kualitas pada tahapan ini dapat dikatakan buruk, karena pengeringan sangat menentukan kualitas teh saat diseduh.

- $\quad$ Sortasi dan Grading

Seperti halnya pada proses pengolahan teh hitam, proses ini bertujuan untuk memisahkan teh kering dari batang besar, batang kecil dan debu, serta melakukan grading jenis mutu agar teh dapat diterima baik dipasaran lokal maupun ekspor. KSU Putera Mekar memproduksi teh kering Iroet dengan 4 kualitas, yaitu kualitas Peko, Super, Jikeng dan Jabrug. Kualitas tersebut dibedakan berdasarkan rumusan petikannya, kualitas peko adalah teh kering yang berasal dari petikan pucuk peko saja, kualitas Super adalah teh kering yang berasal dari petikan medium $(p+2$ dan $p+3)$, dan kualitas jikeng dan jabrug adalah teh kering yang berasal dari petikan campuran (peko, medium, dan kasar).

Proses sortasi pada pabrik teh Iroet dilakukan secara manual dan dikerjakan oleh tiga orang. Kegiatan sortir yang dilakukan hanya memisahkan dan mengumpulkan batang besar saja, kemudian batang-batang besar tersebut akan dijual. Proses pengendalian kualias pada tahapan sortasi dapat dikatakan kurang baik, karena masih banyak batang besar yang terlewat. Hal ini terjadi karena petugas sortir kelelahan dan penerangan pada pabrik tidak bagus atau kurang terang, sehingga kualitas teh kering nya semakin menurun. 
Tidak terdapat proses grading pada tahapan akhir pengolahan produksi teh Iroet. Hal ini terjadi karena saat pemetikan pucuk, rumusan petikan yang digunakan oleh petani adalah petikan campuran, kemudian saat di TPH dan proses produksi pucuk teh tidak di grading berdasarkan rumusan petikannya, sehingga teh yang diproduksi adalah teh kering kualitas jabrug (campuran).

Setelah mengetahui keseluruhan proses produksi, masih terdapat banyak pelanggaran yang dilakukan oleh petani, maupun pekerja pabrik. Pelanggaran tersebut seperti tidak menaati keinginan ketua koperasi, dan tidak melakukan produksi sesuai dengan standar prosedur yang ditentukan. Pelanggaran-pelanggaran berikut telah disimpulkan dan dapat dilihat pada Tabel 3.

Tabel 3. Standar prosedur produksi teh Iroet dan pelanggaran yang dilakukan

\begin{tabular}{|c|c|}
\hline Standar Prosedur yang Harus Dilakukan & Pelanggaran-pelanggaran yang Dilakukan \\
\hline Pemetikan Pucuk & Pemetikan Pucuk \\
\hline $\begin{array}{l}\text { Koperasi meminta petani untuk memetik pucuk } \\
\text { dengan rumusan petikan medium }(p+2 \text { dan } p+3)\end{array}$ & $\begin{array}{l}\text { Petani memetik pucuk dengan rumusan halus, } \\
\text { medium dan kasar (campuran) }\end{array}$ \\
\hline Tempat Penampungan Hasil (TPH) & Tempat Penampungan Hasil \\
\hline $\begin{array}{l}\text { Petugas harus mengelompokkan petikan pucuk } \\
\text { berdasarkan rumusan petikannya dan memasukkan } \\
\text { maksimal } 25 \mathrm{~kg} \text { pucuk basah dalam satu karung. }\end{array}$ & $\begin{array}{l}\text { Petugas tidak mengelompokkan pucuk } \\
\text { berdasarkan rumusan petikan dan memasukkan } \\
\text { 35-40 kg pucuk basah dalam satu karung. }\end{array}$ \\
\hline Proses Pelayuan & Proses Pelayuan \\
\hline $\begin{array}{l}\text { Pekerja pabrik harus memasukkan maksimal } 25 \mathrm{~kg} \\
\text { pucuk basah ke dalam mesin Rottary Panner dalam } \\
\text { satu kali proses pelayuan agar pelayuan merata dan } \\
\text { optimal. }\end{array}$ & $\begin{array}{l}\text { Pekerja pabrik memasukkan } 35-40 \mathrm{~kg} \text { pucuk } \\
\text { basah kedalam mesin Rottary Panner dalam } \\
\text { saatu kali proses pelayuan. }\end{array}$ \\
\hline Proses Penggulungan & Proses Penggulungan \\
\hline $\begin{array}{l}\text { Pekerja pabrik harus memasukkan pucuk yang } \\
\text { sudahdilayukan sebanyak 5-10Kg kedalam mesin } \\
\text { Jackson, dan memberikan wadah dibawah mesin } \\
\text { agar pucuk yang sudah digulung tidak jatuh ke } \\
\text { lantai dan kotor. }\end{array}$ & $\begin{array}{l}\text { Pekerja pabrik hanya memberikan alas berupa } \\
\text { karung yang sudang bolong untuk mewadahi } \\
\text { pucuk, sehingga tidak terjaga kebersihannya. }\end{array}$ \\
\hline
\end{tabular}


Tabel 4. Lanjutan

\begin{tabular}{|c|c|}
\hline Standar Prosedur yang Harus Dilakukan & Pelanggaran-pelanggaran yang Dilakukan \\
\hline Proses Pengeringan & Proses Pengeringan \\
\hline $\begin{array}{l}\text { Pucuk yang telah dilayukan dan digulung harus } \\
\text { dikeringkan melalui dua tahap, agar dapat } \\
\text { mengurangi kadar air hingga } 96 \% \text {, memperbaiki } \\
\text { gulungan teh kering, menjaga warna teh agar tidak } \\
\text { coklat, dan menciptakan aroma teh kering yang } \\
\text { khas. Pengeringan pertama dilakukan di mesin } \\
\text { Repeat selama } 25 \text { menit dengan suhu } 50-55^{\circ} \mathrm{C} \text {, dan } \\
\text { pengeringan kedua dilakukan di mesin Balltea } \\
\text { selama } 80-90 \text { menit dengan suhu } 65-70^{\circ} \mathrm{C} \text {. }\end{array}$ & $\begin{array}{l}\text { Pekerja hanya melakukan pengeringan sekali } \\
\text { yaitu menggunakan mesin repeat, dengan waktu } \\
\text { pengeringan lebih lama sekitar } 45-60 \text { menit, } \\
\text { sehingga kadar air teh hanya berkurang } 80-90 \% \\
\text { saja, warna teh kering terlihat pucat, dan aroma } \\
\text { yang di keluarkan tidak terlalu tajam. }\end{array}$ \\
\hline Sortasi dan Grading & Sortasi dan Grading \\
\hline $\begin{array}{l}\text { Pada tahap sortasi, pekerja harus memisahkan } \\
\text { batang dan dust (debu) yang terbawa saat proses } \\
\text { pengolahan dari teh kering. }\end{array}$ & $\begin{array}{l}\text { Pekerja melakukan sortasi dengan memisahkan } \\
\text { batang dari teh kering, sedangkan dust (debu) } \\
\text { nya dibiarkan tercampur begitu saja. }\end{array}$ \\
\hline $\begin{array}{l}\text { Pada tahap Grading pekerja harus memisahkan teh } \\
\text { kering berdasarkan rumusan petikannya. }\end{array}$ & $\begin{array}{l}\text { Pekerja tidak melakukan grading karena pucuk } \\
\text { teh yang di produksi adalah pucuk campuran, } \\
\text { tidak dipisahkan berdasarkan rumusan petikan } \\
\text { saat di TPH. }\end{array}$ \\
\hline
\end{tabular}

Tabel 3 menunjukkan bahwa proses pengendalian kualitas yang dilakukan KSU Putera Mekar adalah buruk, karena sejak awal proses produksi tidak dilakukan pengendalian kualitas yang baik dan benar, serta banyak kegiatan produksi teh Iroet yang tidak dilakukan sesuai standar prosedurnya sehingga kualitas teh kering Iroet menurun.

\section{KESIMPULAN DAN SARAN}

\section{Kesimpulan}

KSU Putera belum melakukan proses produksi teh Iroet sesuai dengan standar operasional prosedur yang dibuat. Pelanggaran standar operasional prosedur pada prroses produksi teh Iroet terjadi pada semua tahapan produksi, yaitu meliputi dua tahapan diluar pabrik dan empat tahapan didalam pabrik, dua tahapan diluar pabrik adalah proses pemetikan pucuk teh basah dan proses pengumpulan pucuk di tempat penampungan hasil. Empat tahapan didalam pabrik adalah proses pelayuan, penggulungan, pengeringan, serta sortasi dan grading. Berdasarkan enam proses produksi tersebut, tidak ada satupun proses produksi yang sesuai dengan standar prosedur, sehingga 
menyebabkan kualitas produk teh Iroet memburuk dan produk teh Iroet tidak lagi menerima sertifikasi UTZ.

\section{Saran}

Saran bagi KSU Putera Mekar untuk menghadapi pelanggaran standar operasional prosedur pada produksi teh Iroet adalah perlu memberikan sanksi tegas kepada petugas TPH dan pekerja pabrik bagi yang melakukan pelanggaran terhadap standar prosedur. Sanksi yang diberikan dapat berupa peringatan pertama, teguran keras, sampai pemotongan upah kerja. Hal ini bertujuan untuk membentuk disiplin pada diri masing-masing petugas dan pekerja di KSU Putera Mekar. Selain itu juga perlu menambah satu sampai tiga petugas petugas di bagian TPH untuk melakukan grading pucuk teh, dengan sistem upah sesuai dengan pekerjaan yang dilakukan. Koperasi akan mengupah petugas sesuai dengan jumlah pucuk teh yang digrading oleh petugas tersebut, koperasi akan mengupah sekitar Rp200 per kg untuk melakukan grading. Sehingga jika petugas tersebut mampu melakukan grading sebanyak 1 ton pucuk, maka petugas tersebut akan diupah Rp200.000,00.

\section{DAFTAR PUSTAKA}

Anggraini, Q. D., Haryono, H., \& Aksioma, D. F. (2016). Pengendalian kualitas proses produksi teh hitam di PT. Perkebunan Nusantara XII Unit Sirah Kencong. Jurnal Sains dan Seni ITS, 5(2). 327-332.

Anjarsari, I. R. D. (2016). Katekin teh Indonesia: prospek dan manfaatnya. Kultivasi, 15(2), 99106.

Balqis, P., Ibrahim, N. U., \& Ibrahim, S. (2014). Kompetensi Pedagogik Guru dalam Meningkatkan Motivasi Belajar Siswa Pada SMPN 3 Ingin Jaya Kabupaten Aceh Besar. Jurnal Administrasi Pendidikan: Program Pascasarjana Unsyiah, 2(1), 25-38.

Direktorat Jenderal Perkebunan. (2016). Statistik Perkebunan Indonesia 2014-2016. Jakarta: Direktorat Jenderal Perkebunan.

Johan, M. E., Salim, A. A., \& Rachmiati, Y. (2009). Pengaruh Cara Pemetikan Dengan Gunting dan Aplikasi Pemupukan Terhadap Peningkatan Produksi Pucuk Tanaman Teh Asal Biji. Jurnal Penelitian Teh Dan Kina, 11, 17-24.

Kusmiyati, M., Sudaryat, Y., Lutfiah, I. A., Rustamsyah, A., \& Rohdiana, D. (2015). Aktivitas antioksidan, kadar fenol total, dan flavonoid total teh hijau (Camellia sinensis (L.) O. Kuntze) asal tiga perkebunan Jawa Barat. Jurnal Penelitian Teh Dan Kina, 18(2), 101-106.

Moleong, L. J. (1999). Metodologi penelitian. Bandung: PT. Remaja Rosda Karya.

Novasyurahati. (2014). Strategi untuk perbaikan manajemen perkebunan teh rakyat: studi kasus di Kecamatan Pasirjambu dan Ciwidey, Kabupaten Bandung. Jurnal Matematika Dan Sains, 19(2), 33-49.

Rohdiana, D. (2015). Teh: proses, karakteristik dan komponen fungsionalnya. Food Review Indonesia, 10(8), 34-37. 
Sugiyono. (2013). Metode Penelitian Kuantitatif, Kualitatif dan R\&D. Bandung: Alfabeta.

Suharsimi, A. (2010). Prosedur Penelitian: Suatu Pendekatan Praktik (Edisi Revisi). Jakarta: Rineka Cipta.

Suprihatini, R. (2016). Daya saing ekspor teh Indonesia di pasar teh dunia. Jurnal Agro Ekonomi, 23(1), 1-29.

Trimo, L., Fatimah, S., \& Djuwendah, E. (2017). Kajian Pengembangan Agroindustri Berbasis Teh Rakyat. Jurnal Rekayasa Hijau, 1(2), 136-145.

Trimo, L., \& Nurafifah, I. (2017). Study of development of agro-tourism potential on tea smallholder. Jurnal Penelitian Teh dan Kina, 20(1), 36-47.

Wibowo, A., \& Ramadian, D. (2010). Model simulasi kinerja produksi teh untuk minimisasi workin-process. Jurnal Optimasi Sistem Industri, 9(1), 7-12.

Wulansari, R., Rachmiati, Y., Rezamela, E. (2017). Kajian status hara tanah dan tanaman di perkebunan teh Jawa Barat dan Sumatera Utara. Creative Research Journal, 1(01), 16-30. 